\title{
MOGUĆNOSTI PRIMJENE OTPADNIH MATERIJALA KAO AGREGATA U PROPUSNOM BETONU
}

\author{
Ivan Kraus \\ Sveučilište Josipa Jurja Strossmayera u Osijeku, Građevinski fakultet Osijek, mag.ing.aedif. \\ Ana Tirić \\ Sveučilište Josipa Jurja Strossmayera u Osijeku, Građevinski fakultet Osijek, univ.bacc.ing.aedif. \\ Dalibor Burilo \\ Sveučilište Josipa Jurja Strossmayera u Osijeku, Građevinski fakultet Osijek, univ.bacc.ing.aedif.
}

Sažetak: Propusni beton, kao jedan od ključnih elemenata održivog razvoja, primjenu najčešće nalazi zbog povoljnog utjecaja na okoliš. Zbog relativno svijetle boje, u urbanim sredinama umanjuje efekt vrućeg otoka, a mreža spojenih šupljina reducira prometnu buku. Osim toga, ima povoljan utjecaj na okolnu vegetaciju, jer omogućava lakšu infiltraciju vode i kisika u područje korijenja. Radom je obuhvaćen pregled istraživanja na propusnim betonima provedenih u svijetu i daje prikaz rezultata ispitivanja koja su autori proveli na propusnim betonima s drobljenom opekom i zgurom kao agregatom.

Ključne riječi: propusni beton, dolomit, zgura, drobljena opeka, gospodarenje otpadom

\section{POSSIBILITIES OF USING WASTE MATERIALS AS AGGREGATES IN PERVIOUS CONCRETE}

\begin{abstract}
Pervious concrete, as one of the key elements of sustainable development, finds application usually due to its favourable effects on the environment. Due to relatively light colour, in urban areas reduces heat island effect, while interconnected voids reduces traffic noise. Moreover, it has beneficial effect on the surrounding vegetation, as it allows easier infiltration of water and oxygen into the root area. This paper includes an overview of researches conducted on pervious concrete in the world and gives the results of research conducted by the authors on pervious concrete with crushed brick and slag as aggregate.
\end{abstract}

Key words: pervious concrete, dolomite, slag, crushed brick, waste management 


\section{Uvod}

Propusni beton, ili beton bez sitnog agregata, jedan je od ključnih elemenata održivog razvoja, prvenstveno zbog povoljnog utjecaja na okoliš, [1]. Uglavnom se sastoji od standardnog, portland cementa, jedne frakcije agregata i vode. Može biti izrađen bez kemijskih dodataka koji se betonu nerijetko dodaju zbog poboljšanja njegovih određenih svojstava, [2], [3]. Odlika propusnog betona je u strukturi otvorenih pora koja pomaže u održavanju razine podzemnih voda i smanjenju štetnog utjecaja oborinskih voda na ekosustav. Mreža spojenih šupljina reducira buku koja nastaje pri dodiru automobilskih guma i kolnika, a u urbanim sredinama umanjuje efekt zagrijavanja prometnih površina. Uz sve navedeno, ima povoljan utjecaj na okolnu vegetaciju, jer omogućava lakšu infiltraciju vode i kisika u područje korijenja, [4] (slika 1).

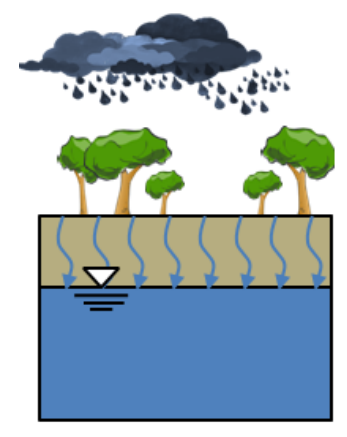

Netaknuti okoliš

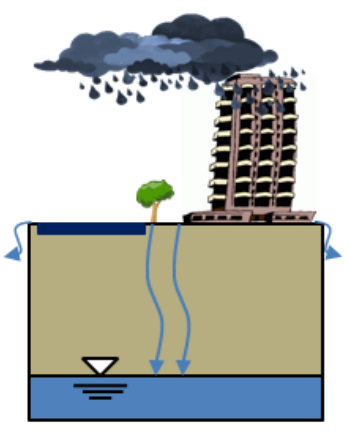

Urbana sredina sa standardnom prometnom površinom

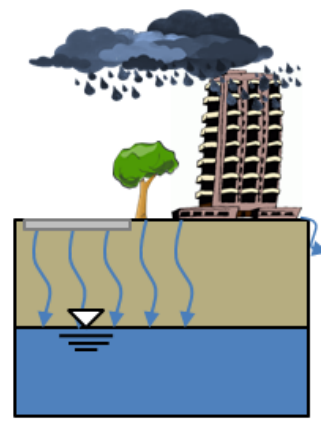

Urbana sredina s prometnom površinom od propusnog betona

\section{Slika 1 - Utjecaj propusnog betona na razinu podzemnih voda u urbanim sredinama [5]} (sliku uredili autori)

Zbog visokog udjela šupljina, propusnom betonu je značajno smanjena tlačna čvrstoća i trajnost u odnosu na standardni beton. No, svojstva propusnog betona mogu se poboljšati odabirom agregata, optimalizacijom sastojaka mješavine te tehnologijom izvedbe $\mathrm{i}$ ugradnje, [6]. Rad daje pregled istraživanja na propusnim betonima provedenih u svijetu te rezultate ispitivanja autora na propusnim betonima sa zgurom, opekom te dolomitom kao agregatom u sastavu. Za izradu betona korišteni su materijali dostupni na području Hrvatske.

\section{Pregled dosadašnjih istraživanja}

\section{Svojstva i sastav propusnog betona}

Sastav propusnog betona ovisi o njegovoj primjeni, zahtijevanim mehaničkim svojstvima i vrsti materijala korištenog pri projektiranju mješavine. Različitim istraživanjima određene su količine materijala koji je potrebno ugraditi da bi propusni beton imao specifičnu strukturu s udjelom šupljina u granicama od 15 do $35 \%$, [2], [3], [7], [8], [9], [10]. Gustoća propusnih betona kreće se u rasponu od 1600 do $2000 \mathrm{~kg} / \mathrm{m}^{3}$, [3].

\section{Udio sastojaka u sastavu betona}

Za izradu propusnog betona preporučeno je dozirati agregat u količini $1190-1600 \mathrm{~kg} / \mathrm{m}^{3}$, [7]. Agregat je uglavnom jednoliko granulirani, veličine 4 - $9 \mathrm{~mm}$, u iznimnim slučajevima $4-12,5 \mathrm{~mm}$, s ili bez dodatka pijeska, [1], [10], [11]. Pijesak, frakcije 0 - 2,36 mm [12], dodaje se u količini od $7 \%$ na ukupnu masu agregata, [10], [12]. Vezivo, portland cement klase I i II, dodaje se u količini $270-415 \mathrm{~kg} / \mathrm{m}^{3}$, [7]. Vodocementni faktor propusnih betona kreće se u granicama $0,20-0,45$, a količina vode koja se dodaje betonskoj mješavini iznosi 75 - 125 $\mathrm{kg} / \mathrm{m}^{3}$, [7]. U propusne betone mogu se ugraditi i razni dodatci poput lateksa, superplastifikatora, polipropilenskih vlakana i aeranata, koji se u mješavinu dodaju prema preporukama proizvođača. 


\section{Tlačna i vlačna čvrstoća}

Zbog velike količine otvorenih šupljina, koje su nerijetko veće od $1 \mathrm{~mm}$, propusni beton ima znatno smanjenu tlačnu čvrstoću koja obično iznosi 20 - $30 \mathrm{MPa}$ [13]. Ipak, u nekim slučajevima tlačna čvrstoća može doseći i 50 $\mathrm{MPa}$, a čvrstoća na savijanje i do $6 \mathrm{MPa}$ [10]. Budući da je prirodni agregat znatno čvršći od cementne paste, lom se najčešće događa preko tankog filma veziva koje obavija agregat. Stoga, jedno od rješenja je poboljšati svojstva cementne paste koja obavija zrna, [13]. Tlačnu čvrstoću je moguće povećati dodatkom pijeska, lateksa te polipropilenskih vlakana ili uporabom agregata manjeg maksimalnog nominalnog zrna, budući da se time povećava dodirna površina između zrna agregata (slika 2). Rezultati ispitivanja dani slikama 2, 3, i 4 provedeni su na betonima s jednozrnatim $(4,75 \mathrm{~mm}, 9,5 \mathrm{~mm}, 12,5 \mathrm{~mm})$ vapnenačkim agregatom u sastavu te običnim portland cementom tipa 1 kao vezivom, [10]. Sve mješavine betona imaju isti vodocementni omjer jednak 0,35, a mješavinama je dodan pijesak izvađen iz rijeke Tennessee; lateks stiren-butadinske gume te polipropilenska vlakna prosječne duljine $20 \mathrm{~mm}$, [10]. Tlačna čvrstoća je mjerena na valjcima promjera $15 \mathrm{~cm}$ i visine $30 \mathrm{~cm}$, [10].

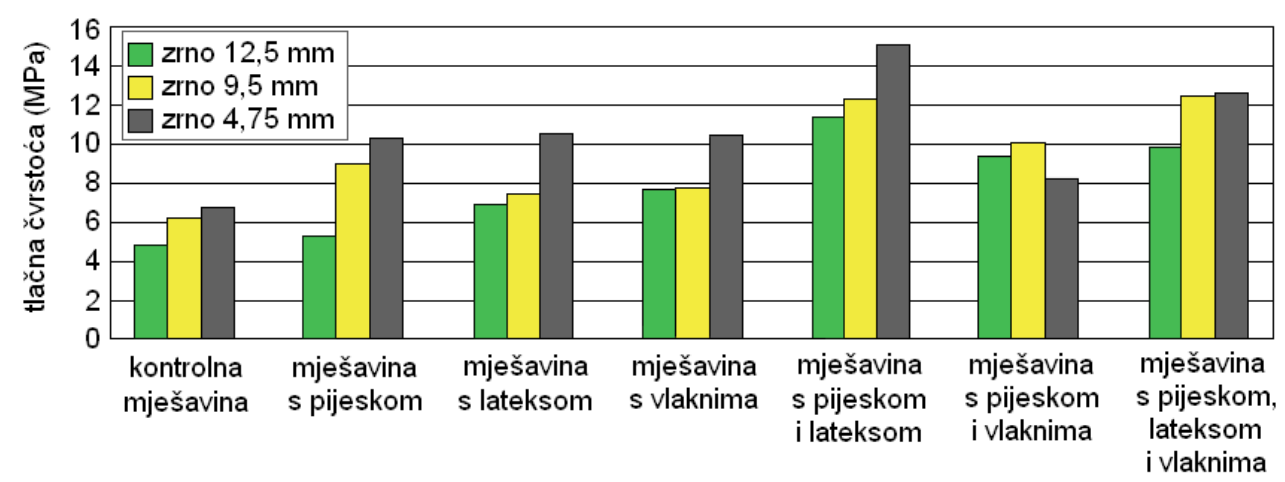

Slika 2 - utjecaj dodataka na tlačnu čvrstoću, [10]

(sliku uredili autori)

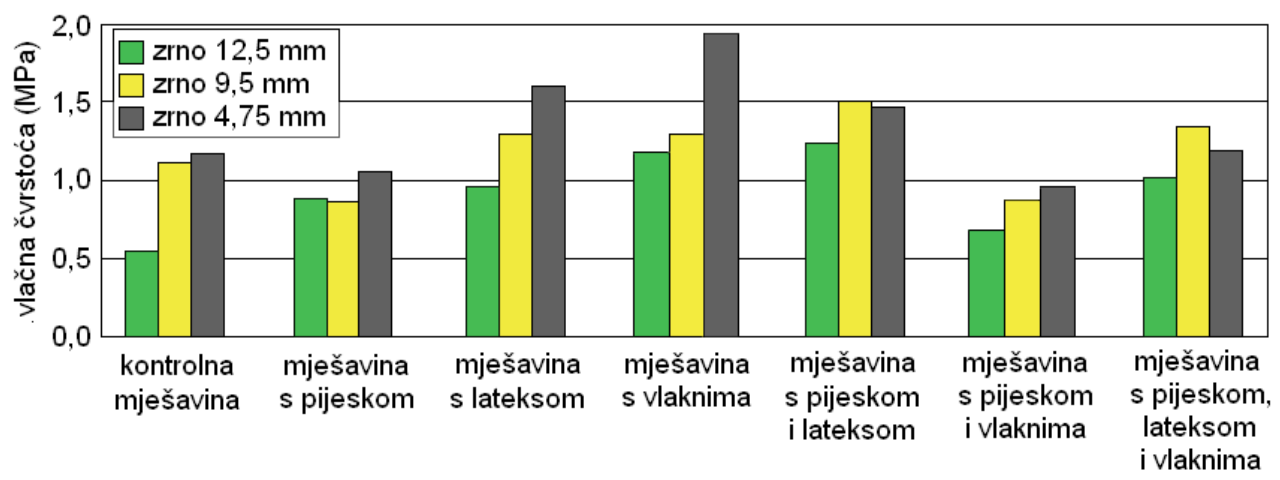

Slika 3 - Utjecaj dodataka na vlačnu čvrstoću, [10]

(sliku uredili autori)

Primjenom dodataka, tlačnu čvrstoću je moguće povećati i za $100 \%$ uz neznatan gubitak poroznosti i propusnosti, [13]. Uočeno je da dodatak vlakana u mješavinu betona koja ne sadrži druge dodatke, znatno povećava tlačnu čvrstoću (slika 2). No, nakon što se mješavini betona s vlaknima dodaju pijesak i/lil lateks, vlakna ne doprinose porastu tlačne čvrstoće (slika 2). Smatra se da je razlog tome nejednolika raspršenost vlakana unutar mješavine betona, [10]. Smanjenje veličine agregata u mješavini propusnog betona doprinosi porastu vlačne čvrstoće (slika 3). Ispitivanjima je pokazano da dodatak pijeska u mješavine propusnog betona može utjecati na smanjenje vlačne čvrstoće (slika 3). Dodatak vlakana ili lateksa u mješavine betona koje ne sadrže druge dodatke, znatno povećava vlačnu čvrstoću (slika 3). Dodatak lateksa i/lil pijeska u mješavine propusnih betona s vlaknima u sastavu, negativno utječu na vlačnu čvrstoću (slika 3). 


\section{Poroznost i propusnost}

Veličina zrna agregata u sastavu betonske mješavine neznatno utječe na poroznost i propusnost (slika 4). Osim toga, uočeno je da se poroznost i propusnost propusnih betona neznatno smanjuju s dodatkom lateksa, pijeska i vlakana (slika 4).

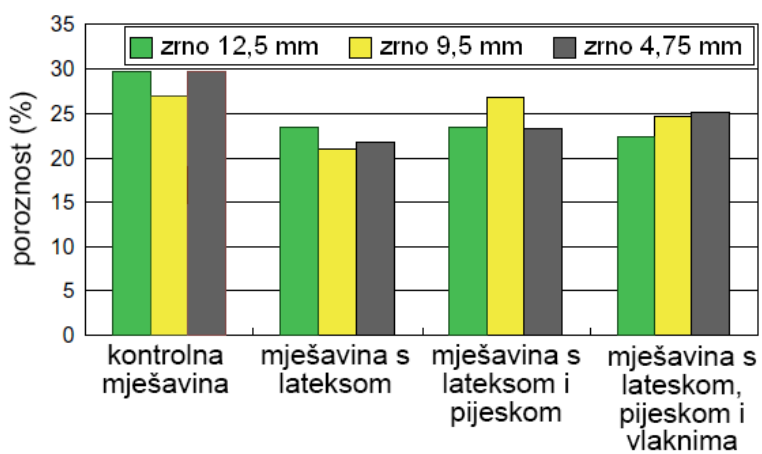

a)

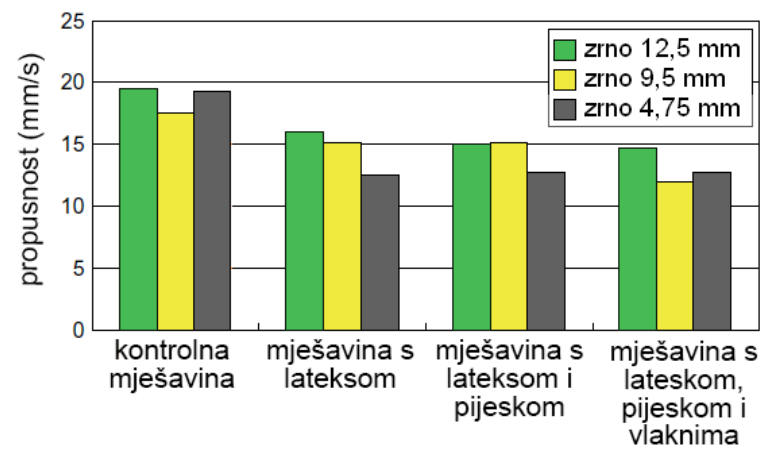

b)

\section{Slika 4 - Utjecaj dodataka i veličine agregata na: a) poroznost; b) propusnost, [10]} (sliku uredili autori)

Prema navodima u [10], prihvatljivom se smatra poroznost u granicama 20 - $30 \%$. Nadalje, smatra se da betoni s propusnošću u granicama $10-20 \mathrm{~mm} / \mathrm{s}$ zadovoljavaju primjenu u drenažnim slojevima prometnica, [10]. Eksperimentalnim istraživanjima je pokazano da propusni betoni koji sadrže vapnenački agregat imaju manju poroznost i propusnost te veću tlačnu i vlačnu čvrstoću u odnosu na propusne betone koji sadrže granit kao agregat, [6].

\section{Apsorpcija zvuka}

Buka koja se širi međusobno povezanim šupljinama u propusnom betonu disipira se i pretvara u toplinu kao rezultat refleksije i ometanja unutar šupljikave strukture betona, [11]. Zvučno izolacijska svojstva propusnog betona prvenstveno ovise 0 teksturi šupljina i veličini zrna agregata, [11]. Eksperimentalnim ispitivanjima je pokazano da betoni s agregatom veličine $10-20 \mathrm{~mm}$ najučinkovitije apsorbiraju zvuk, [11]. Međutim, ako se koristi agregat različitih granulacija i velika količina finog agregata, sposobnost apsorpcije zvuka se smanjuje, budući da takav agregat može zatvoriti šupljine, [8]. Želi li se u očvrslom betonu postići udio šupljina veći od 35\%, nužno je da ukupni volumen betona sadrži približno 50 do $60 \%$ agregata normalne veličine, te 5 do $15 \%$ ukupnog volumena cementne paste, [11]. Ako jeciljana količina šupljina manja od $10 \%$, svojstvo apsorpcije zvuka betona se smanjuje zbog slijeganja cementne paste i začepljenja manjih šupljina, [11].

\section{Trajnost na cikličko zamrzavanje-odmrzavanje}

Uporaba propusnog betona u vlažnom okolišu s mogućnošću izmjeničnog zamrzavanja i odmrzavanja, nije preporučljiva. Trajnost propusnog betona na cikličko zamrzavanje-odmrzavanje se može povećati zamjenom do $7 \%$ mase agregata pijeskom, dodatkom polipropilenskih vlakana, lateksa i/li aeranta, [6], [14]. Uvučeni zrak u cementnoj pasti osigurava prostor za širenje vode zahvaćene unutar betona, čime se smanjuje unutarnji tlak i povećava otpornost na cikličko zamrzavanje-odmrzavanje, [14]. Kako bi se smanjio postotak zasićenja velikih šupljina vodom, što može uzrokovati veliku štetu, ispod prometnih površina od propusnog betona preporuča se izvedba podložnog sloja od drobljenog kamena, [14]. Bolje zbijeni uzorci i uzorci s dodatkom aeranta imaju veću otpornost na cikluse zamrzavanje-odmrzavanje, [6]. 


\section{Prednosti i nedostaci propusnog betona}

Beton je jedan od najzastupljeniji vrsta materijala u građevinarstvu zbog svoje raznolikosti, lakoće kojom se proizvodi i oblikuje, te niske cijene i visoke trajnosti. Osim toga, može sadržavati široki spektar materijala kao agregata. Stoga, beton može poslužiti kao spremnik za otpadni materijal i kao alat u okviru održivog razvoja te pružiti vrijedan spektar ekoloških usluga, integrirajući zelene infrastrukturne sustave u dizajn održivog krajolika, [2]. U kontekstu održivog razvoja, kolnici izrađeni od propusnog betona su znatno isplativiji u odnosu na uobičajene, asfaltne kolnike, [2], [9]. Prometne površine izgrađene od propusnog betona reduciraju otjecanje oborina i potrebu za odvojenim bazenima za pročišćavanje vode, što omogućuje izvedbu manjih odvodnih kanala i vodi ka smanjenju ukupnih troškova projekta. Osim toga, propusni beton omogućuje uspostavljanje hidrološke funkcije, na prirodan način filtrira oborinske vode, čime smanjuje količinu onečišćene vode koja se ulijeva u vodotoke, i povoljno utječe na vegetaciju budući da omogućava protok vode i zraka do korijenja biljaka, [2], [3], [9]. Prometne površine izrađene od propusnog betona svjetlije su od uobičajenih, asfaltiranih prometnih površina te se manje zagrijavaju, što rezultira redukcijom urbanih vrućih otoka, [2], [4], [8], [9]. Najveći nedostatak propusnog betona je niska tlačna čvrstoća koja ograničava njegovu primjenu u prometnicama namijenjenima teškom prometnom opterećenju. Osim toga, niska tlačna čvrstoća utječe na stabilnost i trajnost konstrukcija zbog niske otpornosti na kemikalije, habanje i cikličko zamrzavanje-odmrzavanje. Međutim, prikladno odabranim agregatom, dodatkom finog agregata i organskih primjesa, ovi nedostatci mogu se znatno poboljšati, [10]. Zbog šupljikave strukture, propusni beton ima problema sa začepljivanjem. Da bi se šupljine propusnog betona očistile i učinile ponovno prohodnima, najčešće se primjenjuje vakumsko čišćenje ili pranje vodom pod visokim tlakom, [2], [3].

\section{Primjena propusnog betona}

Propusni beton se poglavito koristi u izvedbi prometnih površina, gdje smanjuje nakupljanje oborinskih voda (slika 5) i time smanjuje opasnost od mogućih prometnih nesreća.

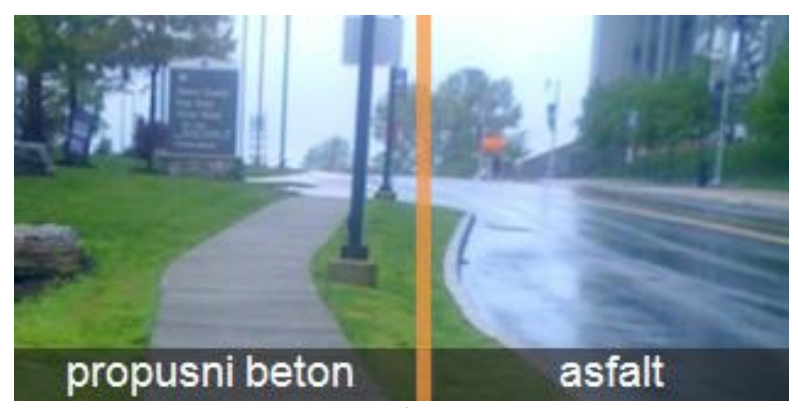

a)

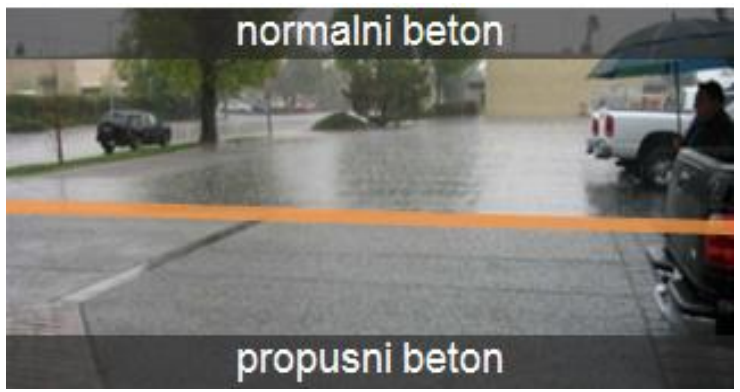

b)

\section{Slika 5 - usporedba vodopropusnosti prometnih površina izrađenih od propusnog betona i drugih materijala: a) pješačka staza i kolnik, [15]; b) parkiralište, [16]}

(slike uredili autori)

Prosječan kolnik izveden od propusnog betona ima propusnost od $143 \mathrm{~L} / \mathrm{min} / \mathrm{m}^{2}$, no propusnost može sezati do vrijednosti od $720 \mathrm{~L} / \mathrm{min} / \mathrm{m}^{2}$, [3]. Prometne površine od propusnog betona omogućuju filtriranje oborinskih voda, reduciraju količinu fosfora i dušika u tlu do $50 \%$ i imaju pozitivan utjecaj na vegetaciju, [3], [4], [8], [9]. Osim toga, prometne površine od propusnog betona, za razliku od asfaltiranih prometnih površina, prilikom izvođenja ili pri zagrijavanju na visokim temperaturama, ne emitiraju štetne plinove, [17]. Eksperimentalna istraživanja provedena na prometnim površinama s premazom od titanovog dioksida $\left(\mathrm{TiO}_{2}\right)$, pokazuju smanjenje onečišćenja u zraku u urbanim sredinama (slika 6), [17]. 


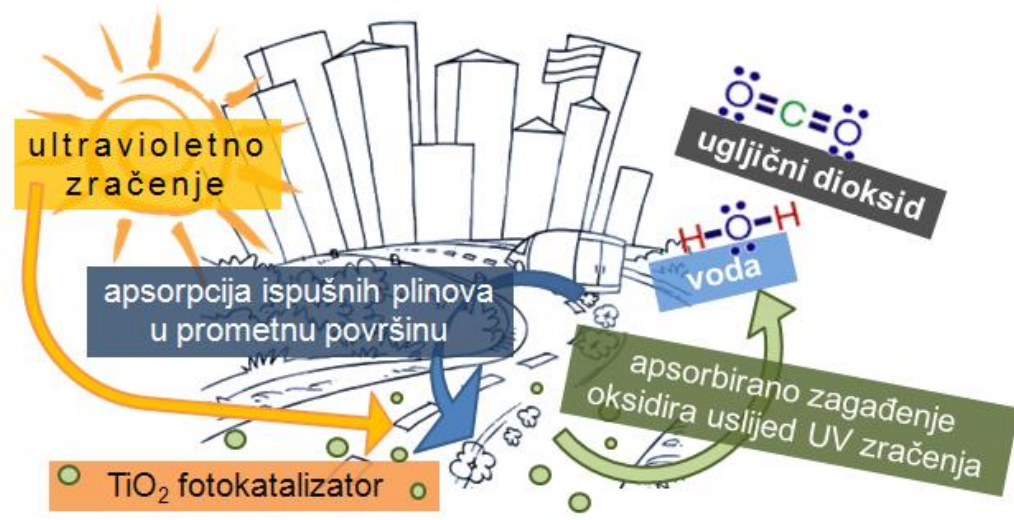

Slika 6 - Fotokatalitički proces na prometnim površinama premazanim titanovim dioksidom, [17] (sliku uredili autori)

Nusprodukti razgradnje zbog djelovanja $\mathrm{TiO}_{2}$ su kisik, ugljični dioksid, voda, sulfati i nitrati, te druge anorganske molekule koje se lako uklanjaju iz prometnih površina vodenim pranjem, [17]. Budući da omogućava opskrbu biljaka vodom i zrakom, propusni beton se u staklenicima koristi za izradu trajnih podloga po kojima je moguće pomicati opremu, [3], [8], [18]. Podovi staklenika načinjeni od poroznog betona mogu prihvatiti vodu te je odvesti prema mjestima za obradu ili bioobnovu, [18]. Nadalje, propusni beton može biti korišten na postrojenjima za uzgoj životinja, za izgradnju podova, hranilica ili područja za pohranu gnojiva, gdje ulogu nalazi u procesu pročišćavanja otpadnih voda, [18]. Propusni beton se koristi i za izradu podova vanjskih sportskih terena, dvorišnih terasa, stabilizacijskih kosina, biciklističkih staza i staza u zoološkim vrtovima te nekližućih podloga oko bazena, [3], [8]. Osim za izradu horizontalnih građevinskih elemenata, zbog dobrih zvučno-izolacijskih svojstava, propusni beton se koristi i za izradu zvučnih pregrada, bukobrana i pročelja zgrada (slika 7), [8], [19].

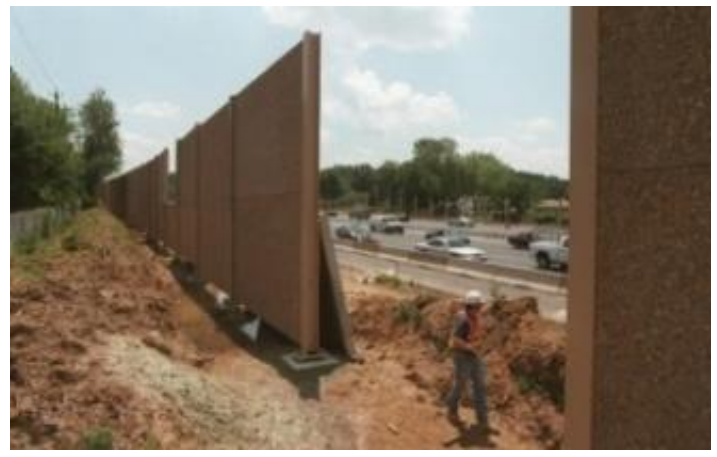

a)

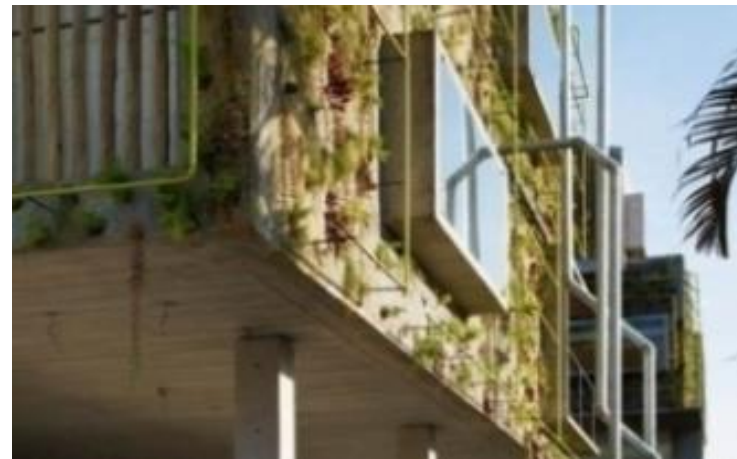

b)

Slika 7 - Vertikalni elementi od propusnog betona: a) bukobran, [20]; b) pročelje uredske zgrade, [21] (slike uredili autori)

\section{Eksperimentalno istraživanje}

Mnoga eksperimentalna istraživanja provedena u svijetu stavila su propusni beton, sa svojim širokim spektrom pozitivnih učinaka na okoliš, visoko u okviru održivog razvoja. Sa svrhom dodavanja vrijednosti propusnom betonu u okviru održivog razvoja, autori su proveli ispitivanja svojstava na propusnim betonima s otpadnim materijalima dostupnim na području Hrvatske. Otpadni materijali korišteni za izradu betonskih mješavina su zgura i drobljena opeka, a izrađene su i dvije mješavine s prirodnim agregatom u sastavu. Uporaba korištenih otpadnih materijala kao agregata u betonu dokazana je, između ostalih, u radovima [22], [23], [24] i [25]. 


\subsection{Sastav betonskih mješavina}

Za ispitivanje mehaničkih i fizikalnih svojstava propusnog betona, pripremljene su mješavine opisane u tablici 1. Sve mješavine imaju istu količinu veziva i vode $(\mathrm{v} / \mathrm{c}=0,3)$ te ciljanu količinu zraka od $15 \%$. Pri spravljanju svih mješavina betona korišten je zasićen, površinski suh agregat frakcije $4-8 \mathrm{~mm}$ i razreda Gc $85 / 20$, te cement CEM II IA-M (S-V) 42,5 N. U mješavine su dodani sljedeći dodatci: polipropilenska vlakna duljine $12 \mathrm{~mm}$ i promjera $18 \mu \mathrm{m}$; superplastifikator na bazi karboksilnih eter polimera te sintetički proizvedena vezivna emulzija na bazi kaučuka (lateks). Ukupni volumen betonske mješavine je sadržavao $10 \%$ pijeska frakcije 0 - 2 mm.

\section{Tablica 1 - Sastav betonskih mješavina}

\begin{tabular}{|c|c|c|c|c|c|c|c|c|c|c|c|c|c|}
\hline \multirow{3}{*}{$\frac{0}{\frac{1}{10}}$} & \multirow{3}{*}{ 을 } & \multicolumn{12}{|c|}{ Količina sastojaka za $1 \mathrm{~m}^{3}$ betona } \\
\hline & & \multicolumn{2}{|c|}{ agregat } & \multicolumn{2}{|c|}{ cement } & \multicolumn{2}{|c|}{ voda } & \multicolumn{2}{|c|}{ superplast. } & \multicolumn{2}{|c|}{ vlakna } & \multicolumn{2}{|c|}{ lateks } \\
\hline & & $\begin{array}{c}\mathrm{m} \\
(\mathrm{kg})\end{array}$ & $\begin{array}{c}\mathbf{V} \\
\left(\mathrm{m}^{3}\right)\end{array}$ & $\begin{array}{c}\mathrm{m} \\
(\mathrm{kg})\end{array}$ & $\begin{array}{c}\mathbf{V} \\
\left(\mathrm{m}^{3}\right)\end{array}$ & $\begin{array}{c}\mathrm{m} \\
(\mathrm{kg})\end{array}$ & $\underset{\left(\mathrm{m}^{3}\right)}{\mathbf{V}}$ & $\begin{array}{c}\mathrm{m} \\
(\mathrm{kg})\end{array}$ & $\begin{array}{c}\mathbf{V} \\
\left(\mathrm{m}^{3}\right)\end{array}$ & $\begin{array}{c}\mathrm{m} \\
(\mathrm{kg})\end{array}$ & $\underset{\left(m^{3}\right)}{\mathbf{V}}$ & $\begin{array}{c}\mathrm{m} \\
(\mathrm{kg})\end{array}$ & $\begin{array}{c}\mathbf{V} \\
\left(\mathrm{m}^{3}\right)\end{array}$ \\
\hline D & $\begin{array}{l}\text { 言 } \\
\frac{\text { 응 }}{0}\end{array}$ & $\begin{array}{c}1835 \\
9\end{array}$ & $\begin{array}{c}670,0 \\
4\end{array}$ & 280,0 & 93,33 & 84,0 & 84,00 & 2,8 & 2,55 & 0,91 & - & - & - \\
\hline 0 & 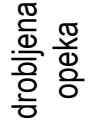 & $\begin{array}{c}1474, \\
0\end{array}$ & $\begin{array}{c}670,0 \\
4\end{array}$ & 280,0 & 93,33 & 84,0 & 84,00 & 2,8 & 2,55 & 0,91 & - & - & - \\
\hline Z & 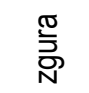 & $\begin{array}{c}2113 \\
3\end{array}$ & $\begin{array}{c}670,0 \\
4\end{array}$ & 280,0 & 93,33 & 84,0 & 84,00 & 2,8 & 2,55 & 0,91 & - & - & - \\
\hline DL & $\begin{array}{l}\overrightarrow{\mathrm{E}} \\
\text { 응 }\end{array}$ & $\begin{array}{c}1835 \\
9\end{array}$ & $\begin{array}{c}670,0 \\
4\end{array}$ & 280,0 & 93,33 & 84,0 & 84,00 & 2,8 & 2,55 & 0,91 & - & 19,89 & 19,60 \\
\hline
\end{tabular}

Mješavina $D$ je referentna i sadrži prirodni agregat, dok mješavine $O$ i $Z$ sadrže redom, drobljenu opeku i zguru. Mješavina DL ima isti sastav kao i mješavina D uz dodatak lateksa. Geometrijska i fizikalna svojstva agregata prikazana su tablicom 2.

\section{Tablica 2 - Geometrijska i fizikalna svojstva agregata}

\begin{tabular}{|l|c|c|c|}
\hline Vrsta agregata & Frakcija $(\mathrm{mm})$ & $\begin{array}{c}\text { Specifična gustoća } \\
\left(\mathrm{kg} / \mathrm{m}^{3}\right)\end{array}$ & Upijanje vode (\%) \\
\hline Dolomit & $4-8$ & 2,74 & 0,8 \\
\hline Drobljena opeka & $4-8$ & 2,20 & 16,7 \\
\hline Zgura & $4-8$ & 3,21 & 3,7 \\
\hline
\end{tabular}

\subsection{Svojstva svježih betonskih mješavina}

Rezultati provedenih ispitivanja na svježim betonskim mješavinama dani su u tablici 3. Konzistencija je ispitana metodom rasprostiranja. Udio pora je ispitan koristeći porometar, no vjerodostojnost metode je upitna jer se koristi za mjerenje zatvorenih pora, dok mješavine propusnog betona sadrže sustav otvorenih pora i šupljina. 


\section{Tablica 3 - Svojstva svježih betonskih mješavina}

\begin{tabular}{|l|c|c|c|c|}
\hline Mješavina & $\begin{array}{c}\text { Konzistencija po } \\
\text { metodi rasprostiranja } \\
(\mathrm{cm})\end{array}$ & $\begin{array}{c}\text { Razred } \\
\text { konzistencije }\end{array}$ & $\begin{array}{c}\text { Gustoća } \\
\left(\mathrm{kg} / \mathrm{m}^{3}\right)\end{array}$ & $\begin{array}{c}\text { Udio pora } \\
(\%)\end{array}$ \\
\hline Dolomit & 43,0 & $\mathrm{~T} 3$ & 2220 & 3 \\
\hline Opeka & 42,0 & $\mathrm{~T} 3$ & 1760 & 6 \\
\hline Zgura & 44,0 & $\mathrm{~T} 3$ & 2460 & 4 \\
\hline Dolomit + Lateks & 47,5 & $\mathrm{~T} 3$ & 2250 & 3 \\
\hline
\end{tabular}

Prilikom ispitivanja nije zapaženo izdvajanje vode ni segregacija agregata. Nakon ispitivanja svojstava u svježem stanju, svi uzorci betona ugrađeni su u kalupe zbijanjem na vibrostolu u trajanju od $30 \mathrm{~s}$.

\subsection{Rezultati}

Očvrsnuli uzorci betona (slika 8) su raskalupljeni nakon $24 \mathrm{~h}$ te potopljeni u vodu. $\mathrm{U}$ starosti od 28 dana su izvađeni iz vode i podvrgnuti ispitivanjima: tlačne čvrstoće na kockama stranice $15 \mathrm{~cm}$ sukladno [26]; vlačne čvrstoće na prizmama izmjera 10/10/40 cm sukladno [27]; propusnosti na valjcima promjera $7,5 \mathrm{~cm}$ i visine 15 $\mathrm{cm}$. Sukladno [28] na kockama stranice $10 \mathrm{~cm}$ određena je specifična gustoća očvrsnulih uzoraka te njihova poroznost.

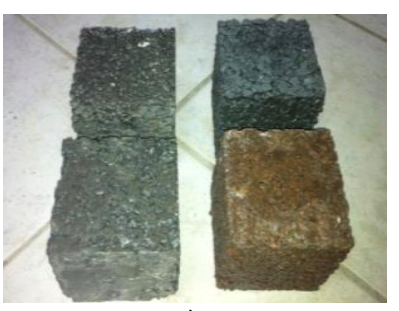

a)

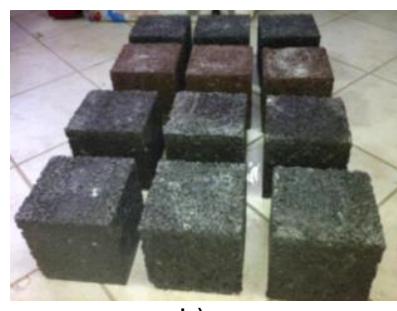

b)

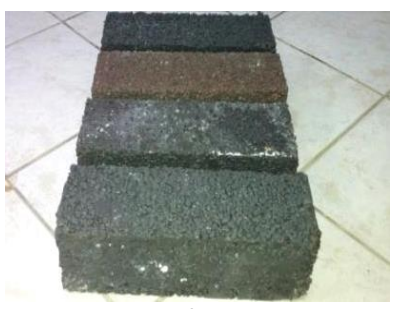

c)

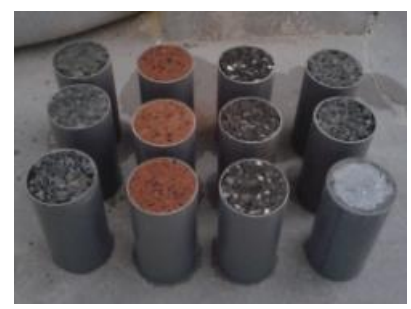

d)

Slika 8 - Očvrsnuli uzorci propusnog betona: a) kocke stranice $10 \mathrm{~cm}$; b) kocke stranice $15 \mathrm{~cm}$; c) prizme izmjera 10/10/40 cm; d) valjci promjera $7,5 \mathrm{~cm}$ i visine $15 \mathrm{~cm}$

Priručnom metodom, mjerenjem brzine snižavanja razine vode u cijevi nastavljenoj na valjke (slika 8d), ispitana je propusnost betona. Eksperimentalnim istraživanjem je utvrđeno da zamjena cjelokupnog prirodnog agregata drobljenom opekom vodi ka smanjenju tlačne čvrstoće od $56 \%$ i smanjenju vlačne čvrstoće od $42 \%$ (slika 9). Zamjena cjelokupnog prirodnog agregata zgurom vodi ka smanjenju tlačne čvrstoće od $16 \%$ i smanjenju vlačne čvrstoće od 29\% (slika 9). Dodatak lateksa betonskoj mješavini s dolomitom rezultira smanjenjem tlačne čvrstoće od $11 \%$ i smanjenjem vlačne čvrstoće od $10 \%$ (slika 9), što je suprotno očekivanim rezultatima. Smatra se da je neprekidna njega u vodi do ispitivanja uzrokom pada tlačne i vlačne čvrstoće očvrsnulih betona $s$ lateksom u sastavu. Slom betonskih uzoraka s prirodnim agregatom i zgurom dogodio se preko cementne paste, dok se slom betonskih uzoraka s drobljenom opekom dogodio preko agregata.

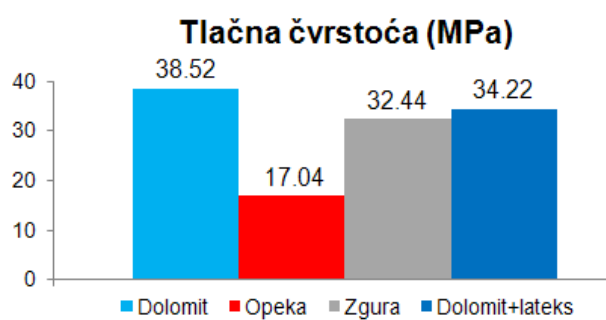

a)

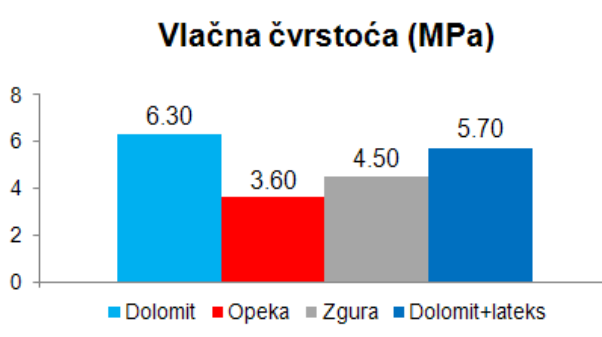

b)

Slika 9 - Mehanička svojstva propusnog betona: a) tlačna čvrstoća; b) vlačna čvrstoća 
Prema definiciji u [29], ispitani propusni betoni s prirodnim agregatom i zgurom, sa specifičnom gustoćom većom od $2600 \mathrm{~kg} / \mathrm{m}^{3}$ (slika 10a), svrstani su u kategoriju teških betona, dok je propusni beton s drobljenom opekom svrstan u kategoriju običnih betona. Betoni s otpadnim materijalima, drobljenom opekom i zgurom, imaju znatno veću poroznost i propusnost u odnosu na betone s prirodnim agregatom (slika 10b i 10c). Tako beton $\mathrm{s}$ drobljenom opekom kao agregatom ima 2,5 puta veću poroznost i 6,8 veću propusnost u odnosu na beton $s$ prirodnim agregatom, dok beton sa zgurom kao agregatom ima 1,6 puta veću poroznost i 4,3 veću propusnost $u$ odnosu na beton s prirodnim agregatom. Beton s lateksom ima 5\% nižu poroznost u odnosu na referentni uzorak i propusnost jednaku nuli (slika 10b i 10c).

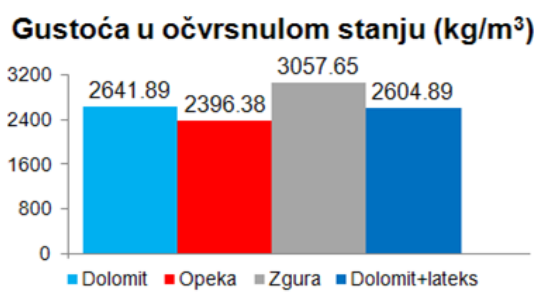

a)

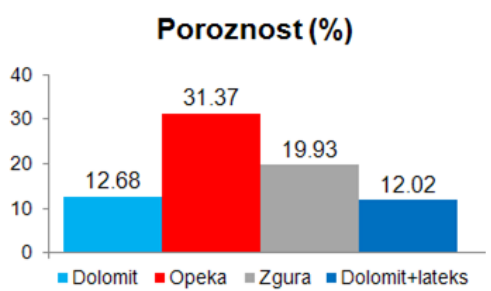

b)

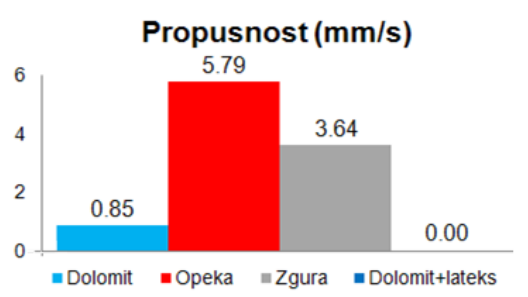

c)

\section{Slika 10 - Fizikalna svojstva propusnog betona: a) gustoća u očvrsnulom stanju; b) poroznost; c) propusnost}

\section{Zaključak}

Propusni beton je važan alat u okviru održivog razvoja koji pomaže u reguliranju odvodnje oborinskih voda, a može koristiti i kao spremnik za otpadni materijal. Zbog svojih dobrih mehaničkih svojstava, visoke vlačne i tlačne čvrstoće, propusni beton sa zgurom i dolomitom u sastavu pogodan je za ugradnju u nosive elemente konstrukcije, dok se beton koji sadrži drobljenu opeku može ugraditi u nenosive elemente. Propusni beton $s$ drobljenom opekom ima 2,5 puta veću poroznost i 6,8 puta veću propusnost u odnosu na beton s prirodnim agregatom te je, zbog niske tlačne čvrstoće, pogodan za izradu podova u staklenicima i postrojenjima za uzgoj životinja, pregradnih zidova, bukobrana i površina za laka prometna opterećenja.

Daljnja istraživanja na propusnim betonima s drobljenom opekom i zgurom trebala bi uključiti i ispitivanja trajnosti na cikličko zamrzavanje i odmrzavanje te apsorpcije zvuka, budući da ova ispitivanja autori nisu mogli provesti zbog nedostatka novčanih sredstava i potrebnih instrumenata za ispitivanja. Osim toga, kako bi se potvrdili ili opovrgnuli rezultati ovog istraživanja, potrebno je provesti dodatna eksperimentalna ispitivanja i numeričke studije na stvarnim konstrukcijama i/ili većem broju uzoraka gdje bi se varirao udio sastojaka u ukupnom sastavu betona.

\section{Literatura}

[1] Sumanasooriya M. S.; Neithalath N. 2011: Pore structure features of pervious concretes proportioned for desired porosities and their performance prediction, Cement \& Concrete Composites, Volume 33, pp 778787

[2] Delatte N.; Schwartz S. S. 2010: Sustainability benefits of pervious concrete pavement, Proceedings of the 2nd International Conference on Sustainable Construction Materials and Technologies, Universita Politecnicadelle Marche, Ancona, Italy, June, pp 28-30, www.claisse.info/2010\%20papers/p14.pdf, pregledano 29.9.2012.

[3] Obla K. H. 2007: Pervious Concrete for Sustainable Development, Recent Advances in Concrete Technology, Washington DC, September, dostupno na: http://www.nrmca.org/research/pervious recent advances in concrete technology0707.pdf, pregledano 7.10.2012.

[4] Voldera A.; Watson T.; Viswanathana B. 2009: Potential use of pervious concrete for maintaining existing mature trees during and after urban development, Urban Forestry \& Urban Greening, Volume 8, pp 249-256 
[5] Handook for pervious concrete certification in Greater Kansas City, Concrete Promotional Group (CPG), Inc., dostupno na: http://www.concretepromotion.com, pregledano 15.11.2012.

[6] Shu X.; et al. 2011: Performance comparison of laboratory and field produced pervious concrete mixtures, Construction and Building Materials, Volume 25, pp 3187-3192

[7] GRACE Construction products, 2006. Pervious concrete mix proportioning. Technical bulletin TB - 0111. dostupno na: http://www.na.graceconstruction.com , pregledano 17.9.2012.

[8] Blažok D. 2010: Propusni beton za kolnike, Tehnički glasnik, Volumen 4, Issue 1-2, pp 15-18, dostupno na: hrcak.srce.hr/file/127819, pregledano 29.8.2012.

[9] Tong B. 2011: Clogging effects of portland cement pervious concrete, Graduate Theses and Dissertations, paper 12048, dostupno na: http://lib.dr.iastate.edu/etd/12048, pregledano 10.10.2012.

[10] Huang B.; Wu H.; Shu X.; Burdette E. G. 2010: Laboratory evaluation of permeability and strength of polymer-modified pervious concrete, Construction and Building Materials, Volume 24, pp 818-823

[11] Kim H. K.; Lee H. K. 2010: Acoustic absorption modeling of porous concrete considering the gradation and shape of aggregates and void ratio, Journal of Sound and Vibration, Volume 329, pp 866-879

[12] Kevern, J. T.; Schaefer, V. R.; Wang, K.; Suleiman, M. T. 2008. Pervious concrete mixture proportions for improved freeze-thaw durability, Journal of ASTM International, Volume 5, Issue 2, pp 1-12, dostupno na: http://k.web.umkc.edu/kevernj/Articles/JAl101320.pdf, pregledano 15.11.2012.

[13] Yang J.; Guoliang J. 2003: Experimental study on properties of pervious concrete pavement materials, Cement and Concrete Research, Volume 33, pp 381-386

[14] Tyner J. S.; Wright W.C.; Dobbs P.A. 2009: Increasing exfiltration from pervious concrete and temperature monitoring, Volume 90, pp 2636-2641, dostupno na: http://cementse.org/PDFs/perv concrete.pdf, pregledano 27.10.2012.

[15] Porous concrete sidewalk at the Penn State Visitors Center in State College, PA. [online slika] preuzeto s: http://melioradesign.net/StormwaterPractices.html, pregledano 27.10.2012.

[16] The pervious installations intermingled with sections of traditional stamped and colored concrete [online slika] preuzeto s: http://www.concretedecor.net, pregledano 27.10.2012.

[17] Shen S.; Burton M.; Jobson B.; Haselbach L. 2012: Pervious concrete with titanium dioxide as a photocatalyst compound for a greener urban road environment, Construction and Building Materials, Volume 35, pp 874-883

[18] Luck J.; Workman S. R.; Coyne M. S.; Higgins S. F. 2008: Solid material retention and nutrient reduction properties of pervious concrete mixtures, Biosystem Engineering, Volume 100, pp 401-408

[19] Putman B. J.; Neptune A. J. 2011: Comparison of test specimen preparation techniques for pervious concrete pavements, Construction and Building Materials, Volume 25, pp 3480-3485

[20] Highway sound barriers block pollution, too, [online slika] preuzeto s: http://weblogs.baltimoresun.com/features/green/2009/12/, pregledano 17.9.2012.

[21] Meinhold B. 2010: Water-recycling building wrapped in a network of tubes [online slika] preuzeto s: http://inhabitat.com/architecture, pregledano 28.10.2012.

[22] Kesegić I.; Bjegović D.; Netinger I. 2009: Upotreba reciklirane opeke kao agregata za beton, Građevinar, Volume 61, Issue 1, pp 15-22

[23] Netinger I.; Jeličić Rukavina M.; Bjegović D. 2010: Mogućnost primjene domaće zgure kao agregata u betonu, Građevinar, Volume 62, Issue 1, pp 35-43

[24] Kesegić I.; Netinger I.; Bjegović D. 2008: Recycled clay brick as an aggregate for concrete: Overview, Tehnički vjesnik, Volume 15, Issue 3, pp 35-40

[25] Netinger I.; Bjegović D.; Varevac D.; Morić D. 2011: Primjena zgure iz čeličana kao agregata u betonu, Građevinar, Volume 63, Issue 2, pp 169-175

[26] HRN EN 12390-3:2002 Ispitivanje očvrsnulog betona - 3. dio: Tlačna čvrstoća uzoraka

[27] HRN EN 12390-5:2009 Ispitivanje očvrsnuloga betona - 5. dio: Čvrstoća ispitnih uzoraka na savijanje

[28] HRN EN 12390-7:2009 Ispitivanje očvrsnuloga betona - 7. Dio: Gustoća očvrsnuloga betona

[29] Mikoč, M. 2006. Građevinski materijali, Građevinski fakultet Sveučilišta Josipa Jurja Strossmayera u Osijeku, Osijek 